\title{
The Effects of Customs Policies on SMEs' Performance
}

\author{
Altina KAMBERAJ ${ }^{\star}$, Ymer HAVOLLI ${ }^{\star \star}$, Naim KAMBERAJ ${ }^{\star \star \star}$
}

\begin{tabular}{l}
\multicolumn{1}{c}{ A R T I C L E I N F O } \\
\hline Article history: \\
Accepted April 2021 \\
Available online May 2021 \\
\hline JEL Classification \\
L24, L25, L88 \\
Keywords: \\
Policies, Customs, Small and \\
Medium-Sized Enterprises, \\
Performance, Entrepreneurship, \\
Kosovo
\end{tabular}

1. Introduction

Government institutions in developing countries are still considered as malformed and fragile in terms of modeling and implementing state policies (Holzner \& Peci, 2011). This has affected the economies of those countries, which suffer from a lack of overall continuity in the economic sector; in particular, these barriers are more pronounced for small and medium-sized enterprises (SMEs) (Iraj Hashi, 2001).

The role of small and medium enterprises due to their ability to respond to external changes and the potential to generate labor has increased at a time when large firms are undergoing a rapid decline (Hashi \& Krasniqi, 2011). In one study (Krasniqi, 2007) has analyzed and has defined that SME growth blocked by the presence of environmental barriers such as unfair competition, inadequate funding, and tax evasion, also denied that SME growth is dependent on the size of the firm and its age. Customs as a state-coordinated policy implementer can have a key role in the livelihoods, functionality, and growth of SMEs as importers or exporters (Liu, 2009). This issue remains to be clarified and evaluated below. The traditional role of Customs is to control the movement of goods and thereby safeguard state interests and maintain revenue collection (European Commission, 2003). The main goals have been to ensure compliance with state policies and laws applicable to cross-border movement of goods, while the more traditional one is to collect other forms of taxation such as Value Added Tax (VAT) and excise duties (Widdowson, 2007; WCO, 2008; Holzner and Peci, 2011; Peterson, 2017). Most countries have faced an exchange between low budget deficit and low taxation imposed on businesses (Hashi, 2001). Expanding the tax base is one solution to the problem because SMEs, especially in countries in the early transition phase, cannot afford high taxes (Krasniqi, 2007). Since 1999, Kosovo has adopted a free-market economy and trade liberalization has been implemented by Kosovo's legislative framework, which is in line with EU legislation (Malush, 2013).

While the role of Customs in developed countries is mainly concerned with protecting the economy and law enforcement, the role of Customs in developing countries focuses on facilitating legitimate trade, combating smuggling, and securing borders (Widdowson, 2007). This role today is generally sought to be changed as a result of factors such as globalization, to overcome so-called 'intervention for the sake of intervention', in contrast to Widdowson (2012), based on the clause 'intervention by exclusion', that is, intervention when it exists a legitimate need to do so; intervention based on identified risk. From this, we note the shift from the traditional role of Customs to the changing role of Customs, a change dating back to the 21st century, an approach supported by Widdowson (2012) and Peterson (2017) as well. With the respect to the authors, we see clearly that there is a link between the policies implemented by Customs and SMEs, and the same cannot be considered in an unstable state, as long as indirectly impacts SMEs, thus

\footnotetext{
${ }^{\star},{ }^{\star \star}$ University of Pristina, Kosovo, ${ }^{\star \star \star}$ MIT University, Skopje, Kosovo. E-mail address: altina-k@hotmail.com (Corresponding author)
} 
facilitating their functionality. Day by day, many aspects and areas are being affected by Globalization as a new spirit.

\section{Literature review}

Kosovar SMEs are playing an important role in Kosovo's economic development (Riinvest, 2001). The establishment and growth of enterprises, especially private ones in transition countries, were characterized by many difficulties and challenges. Kosovo's economy since 1999 has been largely driven by international aid, the public sector, and remittances (World Bank, 2010). Because Kosovo is still in a transition phase, the role of the private sector, especially SMEs, has been relatively weak, and despite this, entrepreneurship and small business creation are expected to play a key role on the road to a modern market economy (Krasniqi, 2007). More than 99\% of enterprises in Kosovo are SMEs (Kosovo SME Development Strategy 2012-2016 with a vision until 2020). According to the Ministry of Finance in Kosova, the average real GDP growth in Kosovo for 2006-2009 was 4.8\%. Based on World Bank report (2010), much of the recent economic progress has been based on donor assistance and remittances, which cannot be the basis for sustainable economic strategies. Kosovo has a young workforce that needs education and training to meet the country's needs for a market economy (Krasniqi, 2007). Kosovo suffers from payment imbalances where imports significantly dominate exports and this is largely because Kosovo's SMEs are not internationally competitive according to Kosovo's SME Development Strategy 2012-2016 with a vision to 2020.

The EC Kosovo Progress Report 2010 (European Commission), identifies three key barriers businesses face in Kosovo. The first barrier concerns the unstable supply of electricity and water which are particularly serious for manufacturing SMEs. The second barrier is limited access to finance, while the third barrier is insufficient to rule of law, which affects all citizens of Kosovo. Customs have traditionally been responsible for implementing a wide range of border management policies, often on behalf of other government agencies, and their role has evolved as a result of a dynamic environment, this reflects the changing environment in which the customs authorities operate and the corresponding changes in government priorities (Widdowson, 2007). The World Trade Organization, the World Customs Organization, and other international bodies are responding by developing global standards that recognize the changing nature of border management (Widdowson, 2012). Moreover (Liu, 2009) emphasizes that trade facilitation is an important goal that the customs authorities of many countries are working hard to achieve. Customs is no longer just a collector of state revenue at the border, but it is responsible for administering international trade and providing the economy and society about the cross-border movement of goods. In its report on Global Economic Prospects for 2005, the World Bank states that "More efficient customs are associated with more trade" (Gordhan, 2007).

\subsection{Development of SMEs in Kosovo}

Kosovar SMEs are playing an important role in Kosovo's economic development (Riinvest, 2001). The establishment and growth of enterprises, especially private ones in transition countries, were characterized by many difficulties and challenges. Kosovo's economy since 1999 has been largely driven by international aid, the public sector, and remittances (World Bank, 2010). Because Kosovo is still in a transition phase, the role of the private sector, especially SMEs, has been relatively weak, and despite this, entrepreneurship and small business creation are expected to play a key role on the road to a modern market economy (Krasniqi, 2007).

More than 99\% of enterprises in Kosovo are SMEs (Kosovo SME Development Strategy 2012-2016 with a vision until 2020). Based on World Bank reports, (2017), much of the recent economic progress has been based on donor assistance and remittances, which cannot be the basis for sustainable economic strategies. Kosovo has a young workforce that needs education and training to meet the country's needs for a market economy (Krasniqi, 2007). Kosovo suffers from payment imbalances where imports significantly dominate exports and this is largely because Kosovo's SMEs are not internationally competitive according to Kosovo's SME Development Strategy 2012-2016 with a vision to 2020. The EC Kosovo Progress Report 2010 identifies three key barriers businesses face in Kosovo. The first barrier concerns the unstable supply of electricity and water which are particularly serious for manufacturing SMEs. The second barrier is limited access to finance, while the third barrier is insufficient to rule of law, which affects all citizens of Kosovo.

\subsection{SMEs' Performance}

The importance of business performance considered by the author Whetten (1983), concretely in strategic management can be discussed along with the three dimensions -namely, theoretical, empirical, and managerial. The theoretical part is sustained and still enriched day by day by numerous authors as may be considered (Whetten, 1983; Lu, 2001; Francis, 2019). In one of the researches conducted by Lu (2001), in the field of SME performance, several hypotheses are raised and their testing indicates whether they are positively significant or rejected. Also, firm size has shown to be negatively correlated with firm performance. Small firms are more limited in their ability to raise capital than their larger competitors, due to their lower stable profits and higher risks (Penrose, 1959). Some results of Voca and Havolli's (2019) research, show that formal education does not affect SME performance, thus justifying that there are many successful SMEs in Kosovo that are managed by entrepreneurs with low levels of education. While the same authors point out that their empirical results have emerged to support the hypothesis that training, career development, and 
motivation result in greater enterprise performance. Based on a research conducted by Ural \& Acaravcl (2006), we can notice that export has not had an impact on the growth of company performance during 19992004, and this explains why export rates in Turkey are very low. On the other hand, empirical and statistical research of Grazzi (2011) conducted in Italian exporting companies, shows that export activity is not systematically related to the profitability of companies. The following explanation; Although exporting companies are more productive, they did not provide any evidence of superior performance in terms of profitability. Eventually, concluding that exports do not necessarily have a positive relationship with performance but, in certain circumstances, and that exporters are no more profitable than non-exporters.

\section{Methodology}

This part defines the research methodology by the purpose of the study, research questions and hypotheses, population and sample selection. Moreover, it explains how data were collected and processed, respondents, and the relevance of this data to the paper. During this research, a quantitative method was used: the questionnaire, which was distributed to SMEs, with emphasis on those enterprises that are in the process of economic impact. The sample was obtained by filtering out enterprises that had fewer than 9 employees and more than 249 employees who are not considered as SMEs because of the capacity and the number of employees. We managed to survey a total of 38 SMEs in the Kosovo region. Although in the sample we had a larger number of firms around 50, as a result of the unwillingness to cooperate we could not execute the questionnaire in those SMEs.

\subsection{Primary and secondary data}

Primary data: Data are collected from the Kosovo Customs webpage - Economic Impact Procedures and implementation of 38 questionnaires in the following municipalities: South Mitrovica (6), North Mitrovica - Zubin Potok (1), Peja (10), Pristina (18), Prizren (1), Fushë Kosovë (1), Istog (1).

Secondary data: Collection of raw data, books, publications, articles, and also information collected from the Customs and Excise Code. This paper uses a number of journals, papers, and articles as well.

\subsection{Distribution of questionnaires}

The type of sample that has been used as part of this survey is 'purposive sample' that is based on the researcher's knowledge and the 'snowball' method: for the Peja and Pristina region.

\subsection{Research questions and hypotheses}

The research questions and hypotheses are as follows:

Do economic impact procedures have effect on SME's performance?

Hypothesis $1_{\mathrm{o}}$ : Economic impact procedures have no effect on the SMEs' performance.

Hypothesis 1: Economic impact procedures have a positive relationship with the SMEs' performance.

Does Import affect SMEs performance?

Hypothesis $1_{\mathrm{o}}$ : Import does not affect SMEs' performance;

Hypothesis 1: As imports increase, so does SMEs' performance as well.

Does Export have effect on SMEs performance?

Hypothesis $1_{\mathrm{o}}$ : Export does not have any effect on SMEs' performance;

Hypothesis 1: Export has a positive impact on SMEs' performance growth.

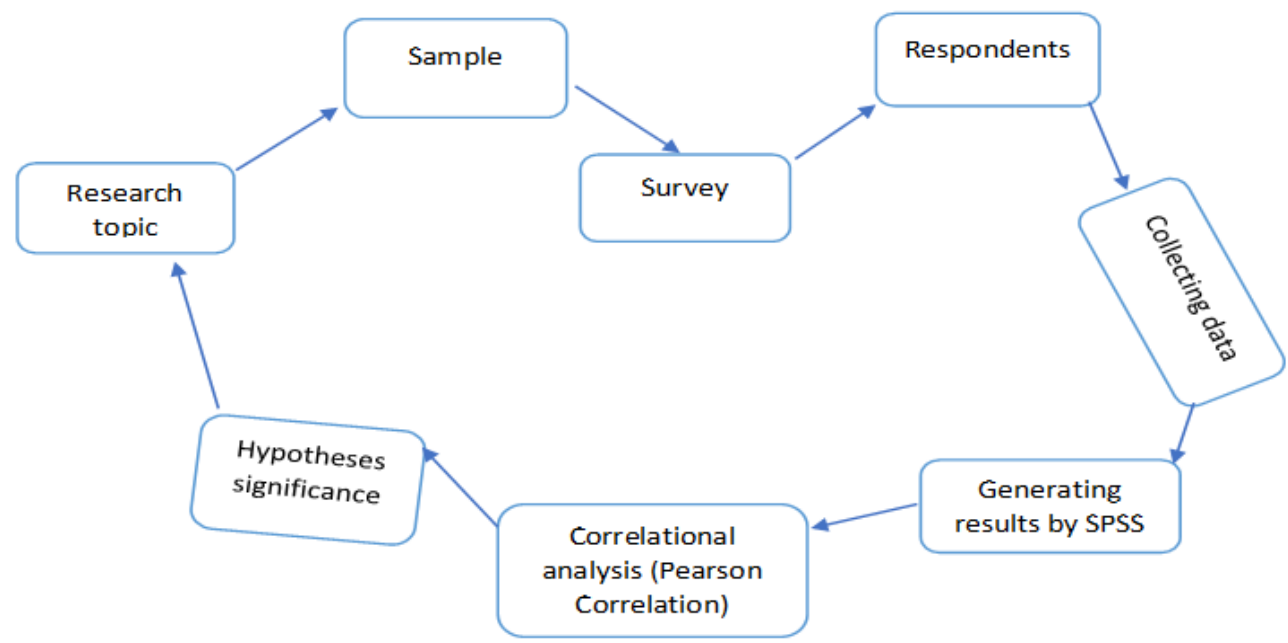

Figure 1. The conceptual model of the methodology part Note: Chronological process of the methodology conceptual model 


\subsection{Hypotheses significance}

As part of the methodology chapter, we considered three research questions and three hypotheses that need to be tested and validated were identified. As a result of many attempts to define a hypothesis that specifically matched the title of the topic, we determined the relationship of economically influential procedures with employee performance within SMEs. Below are presented tested variables and their significance.

Do economic impact procedures have effect on SME's performance?

Hypothesis $1_{0}$ : Economic impact procedures have no effect on the SMEs' performance.

Hypothesis 1: Economic impact procedures have a positive relationship with the SMEs' performance.

While testing the above hypothesis we see that Pearson Correlation turns out to have positive values +.462 and from this, we can conclude that with the increase of the 'Customs Procedures' variable the 'SME performance' increases as well or vice versa. From this test, it turns out that the null hypothesis has no statistical significance.

From the evaluation of the alternative hypothesis, we consider that; economically influential procedures such as customs policies and SME performance have a reciprocal relationship and are positively significant. In addition, the value of Sig. (2-tailed) turned out to be less than $5 \%$ thus affecting the positive signification verification between the two variables presented. During the research work, we have considered two main factors for significant.

\section{Table 1. Correlation: (Custom Procedures/ Performance)}

\begin{tabular}{|c|c|c|c|}
\hline & & $\begin{array}{r}\text { Customs } \\
\text { procedures }\end{array}$ & Performance \\
\hline Customs procedures & $\begin{array}{l}\text { Pearson } \\
\text { Correlation } \\
\text { Sig. (2-tailed) } \\
\mathrm{N}\end{array}$ & 1 & $\begin{array}{r}.462^{* *} \\
.004 \\
38\end{array}$ \\
\hline Performance & $\begin{array}{l}\text { Pearson } \\
\text { Correlation } \\
\text { Sig. (2-tailed) } \\
\mathrm{N}\end{array}$ & $\begin{array}{r}.462^{* *} \\
.004 \\
38\end{array}$ & $\begin{array}{r}1 \\
38\end{array}$ \\
\hline
\end{tabular}

\subsection{Hypothesis testing (Import / Performance)}

The second hypothesis in our research relates to imports and their importance in performance. But the crucial role in our case is worth nothing in the following analysis. Using the correlation analysis between these two variables we will also be able to see the degree of relationship between them.

Does Import affect SMEs performance?

Hypothesis $1_{0}$ : Import does not affect SMEs' performance;

Hypothesis 1: As imports increase, so does SMEs' performance as well.

The correlation results between SME Performance and Import turn out to be negative, this being explained through Pearson Correlation that turns out to be.259 far from 1 and Sig. (2-tailed) much higher than $5 \%$. This proves that the null hypothesis has been accepted. So our research of 38 Respondents such as SMEs shows that imports have no direct relation to the performance of those companies (negatively significant). However, the values have turned out to be positive and this does not mean that in future research other than our case the import will not have a positive relationship with performance. This is because the surveyed companies have stated that not necessarily the products or services being imported are sold, they may remain in stock and may not be sold. Also, those SMEs that import raw materials and expect to reprocess and sell them in the domestic market do not guarantee that they can increase the performance of the company. Kosovo suffers from payment imbalances where imports dominate exports (SME DEVELOPMENT STRATEGY IN KOSOVO 2012-2016 WITH VISION 2020). 
Table 2. Correlation: (Import/Performance)

\begin{tabular}{l|l|rr}
\multicolumn{2}{l|}{} & Performance & Import \\
\hline Performance & Pearson & 1 & .259 \\
& Correlation & & .117 \\
& Sig. (2-tailed) & & 38 \\
& $\mathrm{~N}$ & 38 & 1 \\
\hline Import & Pearson & .259 & 38 \\
& Correlation & .117 & 38 \\
& Sig. (2-tailed) & $\mathrm{N}$ & 38 \\
\hline
\end{tabular}

\subsection{Hypothesis testing (Export / Performance)}

This hypothesis tests and substantiates the relationship between export and performance. Concerning the work of many authors and their valuable work, that export is positively correlated with performance in our research, on the one hand, it has emerged that the authors' hypotheses such as Cooper (1985), and Girma (2004) are supported also from the results of our work. On the other hand, Ural \& Acaravcl (2006) and Grazzi (2011), do not consider export as a variable that directly affects performance but do not completely deny its impact on performance. According to (Okpara \& Kumbiadis, 2008), export affects the growth of SMEs' performance and also this results in the growth of SMEs or (SMEs ' growth). hypothesis.

Building on the Pearson and Sig correlation analysis. (2-tailed) we test and validate the following

Does Export have effect on SMEs performance?

Hypothesis $1_{\mathrm{o}}$ : Export does not have any effect on SMEs' performance;

Hypothesis 1: Export has a positive impact on SMEs' performance growth.

The results corroborate that export has an impact on SME performance since Pearson Correlation has turned out to be +.481 above 0 and close to 1 and indicates that as Export increases SME performance, as well as the Sig test. (2-tailed) indicates the value of 0.002 substantially confirming that Export and Performance have strongly significant relationships. It follows that with the increase of export in these surveyed SMEs the performance of those SMEs increases, on the other hand, with the decline of export, the performance within the companies also falls.

Table 3. Correlation: Export/Performance

\begin{tabular}{|c|c|c|c|}
\hline & & Export & Performance \\
\hline Export & $\begin{array}{l}\text { Pearson } \\
\text { Correlation } \\
\text { Sig. (2-tailed) } \\
\mathrm{N}\end{array}$ & 38 & $\begin{array}{r}.481^{* *} \\
.002 \\
38\end{array}$ \\
\hline Performance & $\begin{array}{l}\text { Pearson } \\
\text { Correlation } \\
\text { Sig. (2-tailed) } \\
\mathrm{N}\end{array}$ & $\begin{array}{r}.481^{* *} \\
.002 \\
38\end{array}$ & 1 \\
\hline
\end{tabular}

\section{Conclusions}

In this paper, the research in problem statement identified the need to define a relationship of customs policies with performance, import, and export. As noted in the literature review section, there are many studies in the field of performance. The interplay of small and medium-sized enterprises with performance management seems to be a very interesting topic and well handled by various authors. The global economic environment, characterized by constant structural changes and increased competitive pressures, contributed to the increasing importance of small and medium-sized enterprises.

Most of the hypotheses have turned out to be positively significant, thus clarifying research questions, giving meaning to each, and giving value at the same time. 
In conclusion, we can summarize the study on these points:

a) Customs policies or economic procedures have positive impact on enhancing SMEs' performance;

b) Import and performance of SMEs have no significant relationship, but the values are positive and it does not mean that in future studies there will be no relationship between these variables;

c) Exports have positive-moderate relationship with SME's employee performance.

This paper leaves open for futher studies the possibility of comparing SMEs that apply economic impact procedures with those that do not apply economic procedures and making comparisons between them.

\section{References}

1. Akhtar, J. (2014). Impact of Work Environment, Salary Package and Employees' Perception on Organizational Commitment. International Journal of Academic Research in Business and Social Sciences, 4, 1-19.

2. Kosovo Embassy in Ankara. (a.d.). Retrieved from: http://www.ambasada-ks.net/tr/?page=1,75

3. Berisha-Namani, M. (2009). The role of information technology in small and medium sized enterprises in Kosova. Fulbright academy conference.

4. Central European Free Trade Agreement. (a.d.). Retrieved from: https://mei.gov.md/en/content/central-european-free-tradeagreement-cefta

5. Cooper, R. G. (1985). The Impact of Export Strategy on Export Sales Performance. . Journal of International Business Studies, $37-55$. doi.org/10.1057/palgrave.jibs.8490441

6. European Commission. (2003). Commission Recommendation of 6 May 2003 concerning the definition of micro, small and mediumsized enterprises. Retrieved from: ELI: http://data.europa.eu/eli/reco/2003/361/oj

7. Gjonbalaj, M., Musliu, A., \& Skender Ahmeti. (2011). Evaluating impact of CEFTA agreement for Kosovo. Anadolu International Conference in Economics II.

8. Gordhan, P. (2007). CUSTOMS IN THE 21ST CENTURY (Vol. i 1). World Customs Journal. Gjetur në https://worldcustomsjournal.org/

9. Grazzi, M. (2011). Export and Firm Performance: Evidence on Productivity and Profitability of Italian Companies. Journal of Industry, Competition and Trade, 413-444. doi:10.1007/s10842-011-0102-9

10. Hashi, I., \& Krasniqi, B. A. (2011). Entrepreneurship and SME growth: Evidence from advanced and laggard transition economies. International Journal of Entrepreneurial Behavior \& Reseach, 17 Iss 5, 456-487. doi.org/10.1108/13552551111158817

11. Hayton, J. C. (2003). Strategic human capital management in SMEs: An empirical study of entrepreneurial performance. Human Resource Management, 375-391. doi:doi:10.1002/hrm.10096

12. Holz, W. (2009). Is the R\&D behaviour of fast-growing SMEs different? 59-75. doi:10.1007/s11187-009-9182-X

13. Holzner, M., \& Peci, F. (2011). The Impact of Customs Procedures on Business. The Vienna Institute for International Economic Studies. Retrieved from: http://hdl.handle.net/10419/203941

14. Iraj Hashi. (2001). Economic Policy in Transitional Economies. 11: 221. doi:doi.org/10.1023/A:1013157127524

15. Khan, M. I. (2012). The Impact of Training and Motivation. THE INSTITUTE OF BUSINESS ADMINISTRATION KARACHI-PAKISTAN, 7.

16. kosoves, D. E. (a.d.). DOGANA E KOSOVES. Retrieved from://dogana.rks-gov.net/per-doganen/historia/: https://dogana.rksgov.net/per-doganen/historia/

17. Kosovo Country Commercial Guide. (2019). Retrieved from: Kosovo - Trade Agreements: https://www.export.gov/article?id=KosovoTrade-Agreements

18. Kotler, P. (2011). Philip Kotler's Contributions to Marketing Theory and Practice. Review of Marketing Research, 87-120. doi:10.1108/S1548-6435(2011)0000008007

19. Krasniqi, B. (2007). BARRIERS TO ENTREPRENEURSHIP AND SME GROWTH IN TRANSITION: THE CASE OF KOSOVA. doi:10.1142/S1084946707000563

20. Krasniqi, B. A. (2007). BARRIERS TO ENTREPRENEURSHIP AND SME GROWTH IN TRANSITION: THE CASE OF KOSOVA. Journal of Developmental Entrepreneurship, 12, 71-94. doi.org/10.1142/S1084946707000563

21. Kraus, S. R. (2012). Entrepreneurial orientation and the business performance of SMEs: a quantitative study from the Netherlands. Rev Manag Sci 6. doi:doi.org/10.1007/s11846-011-0062-9

22. Liu, D. (2009). Warehousekeepers: bridges connecting Customs and small and medium-sized enterprises (SMEs). World Customs Journal.

23. Lu, J. W. (2001). The internationalization and performance of SMEs. Strategic Management Journal, 565-586. doi:doi.org/10.1002/smj.184)

24. Malush, T. (2013). Problems of Start-Ups in Transition Economies. International Journal of Business and Management Studies Internati, Vol 5, No 2,.

25. Mathur, L. K., \& Mathur, I. (1997). The Effectiveness of the Foreign-Trade Zone as an Export Promotion Program: Policy Issues and Alternatives. Journal of Macromarketing, 2, 20-31. doi:doi.org/10.1177/02761467970170

26. Ministria e Integrimit Evropian. (a.d.). Retrieved from: https://www.mei-ks.net/sq/procesi-i-stabilizim-asociimit-78

27. Neziraj, E., \& Berisha-Shaqiri, A. (2017). Impact of Information Technology on the Innovation Processes:. International Journal of Economic Perspectives, 277-286. Retrieved from: https://www.researchgate.net/profile/

28. Penrose, E. (1959). The Theory of the Growth of the Firm. New York: John Wiley. New York: Oxford University Press Inc., New York.

29. Peterson, J. (2017). An Overview of Customs Reforms to Facilitate Trade. Journal of International Commerce and Economics. Retrieved from: https://www.usitc.gov/journals

30. Relations between Kosovo and Turkey. (a.d.). Retrieved from: MINISTRY OF FOREIGN AFFAIRS, Republic of Turkey: http://www.mfa.gov.tr/relations-between-turkey-and-kosovo_.en.mfa

31. Rotar, L. J., Pamić, R. K., \& Bojnec, Š (2019). Contributions of small and medium enterprises to employment in the European. Economic Research-Ekonomska Istraživanja, 3296-3308. doi.org/10.1080/1331677X.2019.1658532

32. Rynes, S. L. (2004). The importance of pay in employee motivation: Discrepancies between what people say and what they do. Human Resource Management, 381-394. doi:10.1002/hrm.20031

33. Svejnar, J. (2002). Transition Economies: Performance and Challenges. The Journal of Economic Perspectives, Vol. 16, No. 1 , 3-28. Retrived from: https://www.jstor.org/stable/2696574

34. Ural, T., \& Acaravcl, S. K. (2006). "The Effects of Firm's Strategic Factors on Export and Firm Performance: A Comparison of Permanent and Sporadic Exporters". "Problems and Perspectives in Management", 4, 22. 
35. Van D. Knippenberg. (2002). Work Motivation and Performance: A Social Identity Perspective. Applied Psychology. Applied Psychology, 357-371. doi:doi:10.1111/1464-0597.00020

36. Vesel, K. S. (a.d.). Regional Entrepreneurship Dynamics: The Case of Czech Republic. Procedia - Social and Behavioral Sciences. doi:10.1016/j.sbspro.2013.04.048

37. Voca, Z., \& Havolli, Y. (2019). The Impact of Human Resources Development on Small and Medium Enterprises (SMEs) Performance: The Case of Kosovo. Journal of Economics and Management Sciences, 2. doi:doi.org/10.30560/jems.v2n2p45

38. Vranja, L. (2017). The impact of the CEFTA trade agreement on economic development in Kosovo. doi:doi.org/10.21113/iir.v7i1.303

39. Vroonhof, P. (2011). Do SMEs create more and better jobs? EIM Business \& Policy Research . EIM. Retrieved from: https://ec.europa.eu/growth/sites/growth/files/docs/body/do-smes-create-more-and-better-jobs_en.pdf

40. WCO. (2008). CUSTOMS IN THE 21ST CENTURY.

41. Whetten, K. C. (1983). Organizational effectiveness: A comparison of multiple models. Journal of Policy Analysis and Mangement, 477487. doi:10.1002/pam.4050030351

42. Widdowson, D. (2007). 'The changing role of customs: evolution or revolution?'. World Customs Journal,, Vol. 1, No. 1, , 31 -37.

43. Widdowson, D. (2007). THE CHANGING ROLE OF CUSTOMS: EVOLUTION OR REVOLUTION? International Network of Customs Universities. Retrieved from: worldcustomsjournal.org

44. Widdowson, D. (2012). THE CHANGING ROLE OF CUSTOMS: World Customs Journal .

45. Williams, C. C. (2008). Beyond Necessity-Driven Versus Opportunity-Driven Entrepreneurship. The International Journal of Entrepreneurship and Innovation, 157-165. doi.org/10.5367/000000008785096647

46. *** (2001). "SMES Financial Development", Investigation draft. RIINVEST. Retrieved from: https://www.esiweb.org/pdf/bridges/kosovo/20/21.pdf 